\title{
Greenhouse gas emissions and surface water management
}

\author{
Anne Marieke Motelica-Wagenaar and Jos Beemster \\ Waternet, Amsterdam, P.O. Box 94370, the Netherlands \\ Correspondence: Anne Marieke Motelica-Wagenaar (anne.marieke.motelica@waternet.nl)
}

Published: 22 April 2020

\begin{abstract}
Soil subsidence is one of the major issues in the management area of the water authority Amstel, Gooi and Vecht, including emissions of greenhouse gases. This paper describes four different methods to calculate these emissions in agricultural peat meadows, based on (1) the mean lowest groundwater level, (2) the mean groundwater level, (3) the subsidence rates and (4) general numbers. The emissions were calculated in two polders (about 2600 ha peat meadow), these were comparable for all methods, ranging from 42 up to $50 \mathrm{kton} \mathrm{CO}_{2}$ eq $\mathrm{yr}^{-1}$ (based on data of 2015), which is about 14.5 up to $19 \mathrm{tCO}_{2}$-eq ha ${ }^{-1} \mathrm{yr}^{-1}$. Besides, the greenhouse gas emissions were compared for different policy scenario's in one polder subunit (283 ha): (1) standard policy (lowering surface water level at the same rate as soil subsidence taking place), (2) passive rewetting (surface water level fixation), (3) subsurface irrigation by submerged drains, and (4) a maximum surface water level decrease of $6 \mathrm{~mm} \mathrm{yr}^{-1}$. Comparing the four policy scenario's in one polder subunit, greenhouse gas emissions were lowest in case of subsurface irrigation, decreasing greenhouse gas emissions by about $35 \%-50 \%$ in this polder compared to standard policy, meaning a decrease of about 5.5-9.3 $\mathrm{tCO}_{2}$-eq ha ${ }^{-1} \mathrm{yr}^{-1}$. This represents a value of about 550-930 EUR ha-1 $\mathrm{yr}^{-1}$ (at a price of EUR 100 per ton $\mathrm{CO}_{2}$-eq). The scenario passive rewetting leads to a decrease of about $12 \%-21 \%$, or $2-3 \mathrm{tCO}_{2}$-eq ha ${ }^{-1} \mathrm{yr}^{-1}$ compared to standard policy. The estimation of the decrease in GHG emissions depends on the assumptions made. In this study it was assumed that subsurface irrigation halves soil subsidence. The water board will use the described procedures to estimate greenhouse gas emissions in the future to support water level management in areas with peat soils.
\end{abstract}

\section{Introduction}

Waternet is the executive agency of the regional water authority Amstel, Gooi and Vecht (AGV). Soil subsidence is one of the major issues in the management area of AGV, including emissions of greenhouse gases (GHG). Different methods exist to estimate GHG emission from peat soils. In Waternet, a literature study was done to estimate GHG emissions (Stoffels, 2009). Another estimation can be performed based on mean groundwater levels (Jurasinski, 2016). In the model RE:PEAT, $\mathrm{CO}_{2}$ emissions are estimated based on estimated soil subsidence (van den Akker et al., 2008). This model is applied in the study of PBL to estimate the societal costs of soil subsidence in the Netherlands (van den Born et al., 2016). Finally, for the national counting of $\mathrm{CO}_{2}$ emissions, emissions are estimated based on general numbers in peat meadows (Arets et al., 2016; RIVM, 2016).
The question was if calculations of GHG emissions based on these different methods would give comparable outcomes. A method is developed to calculate these emissions as a final step in groundwater modelling. It was hypothesized that GHG estimations in part of the water management area would be comparable for different methods $( \pm 25 \%)$.

In this paper these methods are also used to evaluate GHG emissions of different policies. It was expected that the formulated scenario's in this study (passive rewetting, applying subsurface irrigation and lowering surface water level at a rate of $6 \mathrm{~mm} \mathrm{yr}^{-1}$ ) would lower GHG emissions compared to the current emissions (with standard policy). 


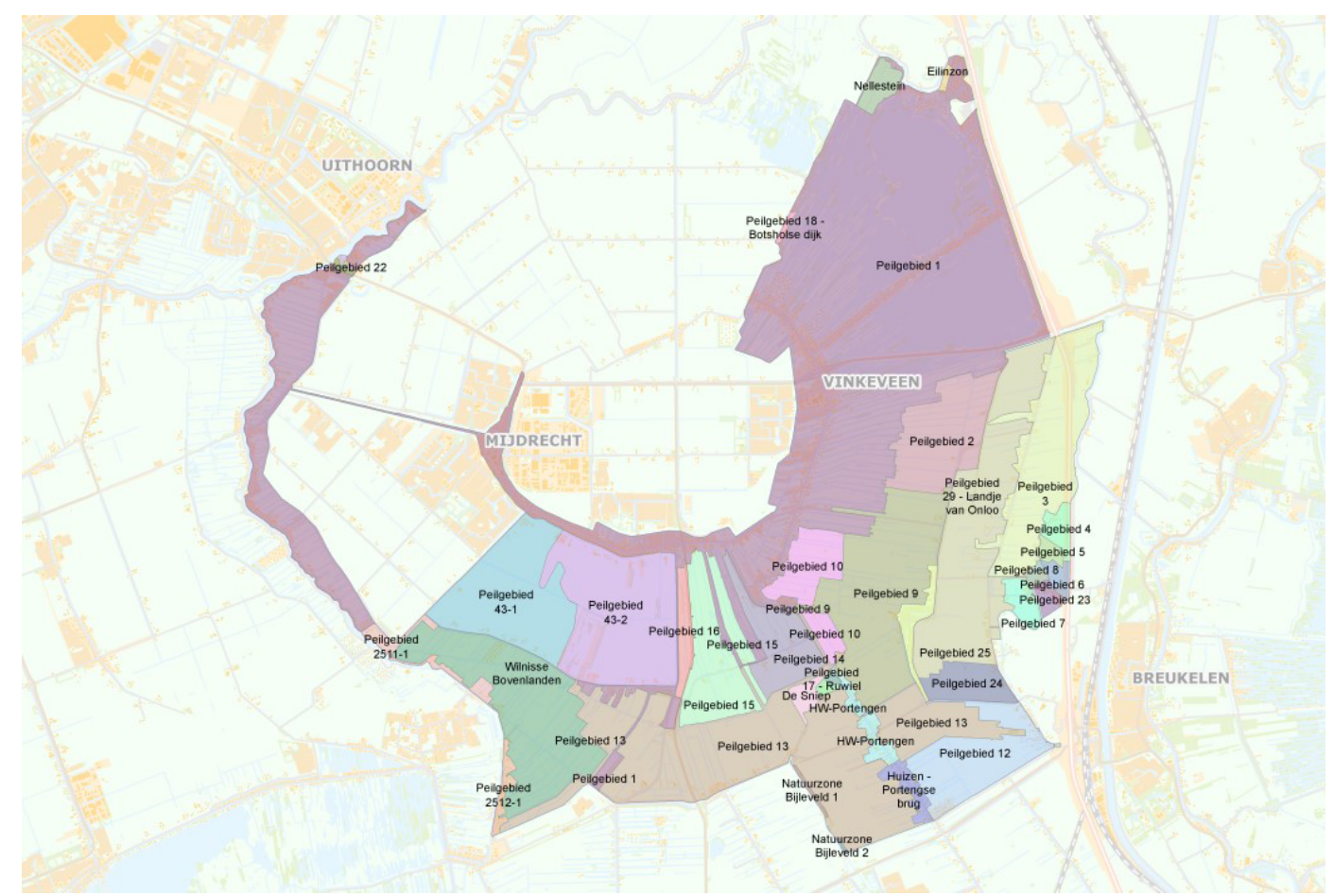

Figure 1. Area of investigation Groot Wilnis-Vinkeveen and Wilnis-Veldzijde, with division into polder subunits (source of topographic underlayer: (C) Kadaster, 2016).

\section{Materials and Methods}

\subsection{Research area}

In this study, current GHG emissions in the agricultural peat lands of Groot-Wilnis Vinkeveen and Wilnis-Veldzijde are calculated (about 2600 ha peat meadows), see Fig. 1. The GHG in the water bodies or built area are not calculated.

It is common practice that the water authority lowers the surface water levels in the same rate as the soil subsidence that has taken place since the last level correction. In a part of Groot Wilnis-Vinkeveen a convenant is made, meaning that the surface water levels will be lowered at a maximum rate of $6 \mathrm{~mm} \mathrm{yr}^{-1}$. Soil subsidence rates in this research area were estimated based on historical data for 18 polder subunits in the research area (data not shown).

GHG emissions were calculated for different policies in one polder in Groot-Wilnis Vinkeveen: polder subunit 9 (about 283 ha peat meadows).

\subsection{Methods to calculate current GHG emissions}

Different methods were compared to calculate current GHG emissions (2015), which are shortly described in Table 1.

Figure 2 shows the $\mathrm{CO}_{2}$-eq emission based on method 1 developed at Waternet. GHG emissions at different mean lowest groundwater levels were interpolated to gain a relation between mean lowest groundwater table and total GHG

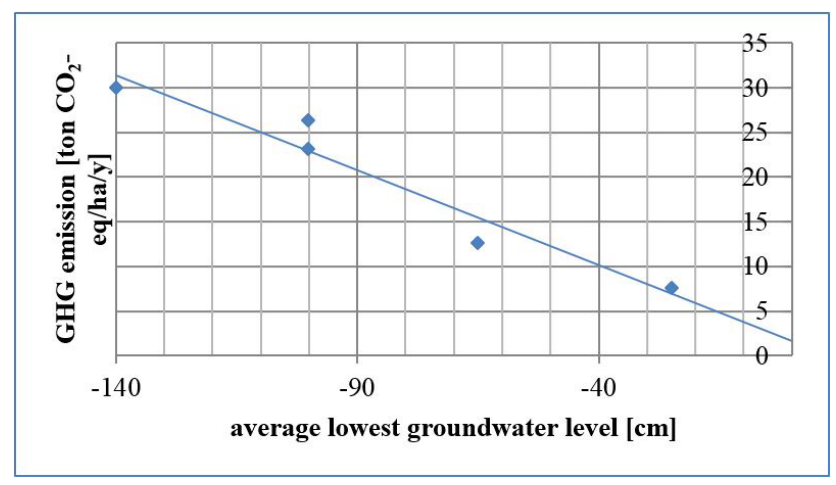

Figure 2. GHG emissions as a function of average lowest groundwater level (Stoffels, 2009).

emissions. In this method, global warming potentials of $\mathrm{N}_{2} \mathrm{O}$ and $\mathrm{CH}_{4}$ were based on IPCC 2007 (as $298 \mathrm{~kg} \mathrm{CO}_{2}$-eq kg for $\mathrm{N}_{2} \mathrm{O}$ and $25 \mathrm{~kg} \mathrm{CO}_{2}$-eq kg${ }^{-1}$ for $\mathrm{CH}_{4}$ ) (IPCC, 2007).

Figure 3 shows the $\mathrm{CO}_{2}$-eq emission based on method 2 (Jurasinski et al., 2016). It is assumed that the $\mathrm{CO}_{2}$ emission depends linear on mean groundwater level. Derived from the graph (Fig. 3), GHG emissions $\mathrm{N}_{2} \mathrm{O}$ and $\mathrm{CH}_{4}$ are estimated, shown in Table 2. In this method, a correction of $\mathrm{CO}_{2}-$ emission is performed in case of presence of a clay cover (see Tables 1 and 2). The global warming potentials of $\mathrm{N}_{2} \mathrm{O}$ and $\mathrm{CH}_{4}$ were based on IPCC (2014) (as $265 \mathrm{~kg} \mathrm{CO}_{2}$-eq kg ${ }^{-1}$ for $\mathrm{N}_{2} \mathrm{O}$ and $28 \mathrm{~kg} \mathrm{CO}_{2}$-eq kg ${ }^{-1}$ for $\left.\mathrm{CH}_{4}\right)$. 
Table 1. Methods used to calculate GHG emissions due to soil subsidence.

\begin{tabular}{|c|c|c|c|c|c|}
\hline No. & Method & $\begin{array}{l}\text { GHG emission } \\
{\left[\mathrm{tCO}_{2} \text {-eq ha } \mathrm{hr}^{-1} \mathrm{yr}^{-1}\right]=}\end{array}$ & $\begin{array}{l}\text { Input data } \\
\text { needed besides } \\
\text { area of peat }\end{array}$ & Background & $\begin{array}{l}\text { GHG } \\
\text { esti- } \\
\text { mated }\end{array}$ \\
\hline 1 & $\begin{array}{l}\text { Waternet (Stof- } \\
\text { fels, 2009) }\end{array}$ & $\begin{array}{l}-0.212 \quad\left[\mathrm{tCO}_{2} \mathrm{ha}^{-1} \mathrm{yr}^{-1} \mathrm{~cm}^{-1}\right] \\
\text { mean lowest groundwaterlevel }[\mathrm{cm}]+ \\
1.677\left[\mathrm{tCO}_{2} \mathrm{ha}^{-1} \mathrm{yr}^{-1}\right]\end{array}$ & $\begin{array}{l}\text { mean lowest } \\
\text { groundwater } \\
\text { table }\end{array}$ & $\begin{array}{l}\text { This method is developed based on } \\
\text { a literature study of GHG emissions } \\
\text { in Dutch peat meadows in grass land } \\
\text { (Stoffels, 2009), see Fig. } 2 \text {. }\end{array}$ & $\begin{array}{l}\mathrm{CO}_{2} \\
\mathrm{~N}_{2} \mathrm{O} \\
\text { and } \\
\mathrm{CH}_{4}\end{array}$ \\
\hline 2 & $\begin{array}{l}\text { Jurasinski et } \\
\text { al. (2016) }\end{array}$ & $\begin{array}{l}-0.408 * \text { (mean groundwater level [cm } \\
-\mathrm{mv}]- \text { clay cover }[\mathrm{cm}])+ \text { emission } \\
\mathrm{N}_{2} \mathrm{O}\left[\mathrm{tCO}_{2}-\mathrm{eq} \mathrm{ha}^{-1} \mathrm{yr}^{-1}\right]+\text { emis- } \\
\text { sion } \mathrm{CH}_{4}\left[\mathrm{tCO}_{2} \text {-eq ha } \mathrm{yr}^{-1}\right] \text { (see } \\
\text { Table 2) }\end{array}$ & $\begin{array}{l}\text { mean ground- } \\
\text { water level clay } \\
\text { cover }\end{array}$ & $\begin{array}{l}\text { This method is used by GDNK (2018). } \\
\text { This method is developed based on a lit- } \\
\text { erature study by Jurasinski et al. (2016), } \\
\text { see Fig. } 3 \text {. }\end{array}$ & $\begin{array}{l}\mathrm{CO}_{2} \\
\mathrm{~N}_{2} \mathrm{O} \\
\text { and } \\
\mathrm{CH}_{4}\end{array}$ \\
\hline 3 & $\begin{array}{l}\text { Van den Akker } \\
\text { et al. }(2008)\end{array}$ & $\begin{array}{l}2.3\left[\mathrm{CO}_{2} \mathrm{ha}^{-1} \mathrm{~mm}^{-1}\right] \cdot \text { soil subsidence } \\
{\left[\mathrm{mm} \mathrm{yr}^{-1}\right]}\end{array}$ & $\begin{array}{l}\text { subsidence } \\
\text { rates }\end{array}$ & $\begin{array}{l}\text { This method is used by PBL (van den } \\
\text { Born et al., 2016). }\end{array}$ & $\mathrm{CO}_{2}$ \\
\hline 4 & $\begin{array}{l}\text { Arets et } \\
\text { al. }(2016)\end{array}$ & $19 \mathrm{tCO}_{2} \mathrm{ha}^{-1} \mathrm{yr}^{-1}$ & - & $\begin{array}{l}\text { This method was used for the national } \\
\mathrm{CO}_{2} \text { counting by RIVM (RIVM, 2016). }\end{array}$ & $\mathrm{CO}_{2}$ \\
\hline
\end{tabular}

Table 2. Emissions of $\mathrm{CO}_{2}, \mathrm{CH}_{4}$ and $\mathrm{N}_{2} \mathrm{O}$ (derived from Jurasinski et al., 2016).

\begin{tabular}{|c|c|c|c|c|c|}
\hline $\begin{array}{r}\text { Mean annual } \\
\text { water level }\end{array}$ & $\begin{array}{r}\mathrm{CO}_{2} \\
\text { emission }\end{array}$ & $\begin{array}{r}\mathrm{CH}_{4} \\
\text { emission }\end{array}$ & $\begin{array}{r}\mathrm{N}_{2} \mathrm{O} \\
\text { emission }\end{array}$ & $\begin{array}{r}\mathrm{CO}_{2} \text {-eq emission } \\
\mathrm{CH}_{4} \text { and } \mathrm{N}_{2} \mathrm{O}\end{array}$ & $\begin{array}{r}\text { Total } \\
\mathrm{CO}_{2} \text {-eq emission }\end{array}$ \\
\hline$[\mathrm{cm}]$ & {$\left[\mathrm{tha}^{-1} \mathrm{yr}^{-1}\right]$} & {$\left[\mathrm{kg} \mathrm{ha}^{-1} \mathrm{yr}^{-1}\right]$} & {$\left[\mathrm{kg} \mathrm{ha}^{-1} \mathrm{yr}^{-1}\right]$} & {$\left[\mathrm{tha}^{-1} \mathrm{yr}^{-1}\right]$} & {$\left[\mathrm{tha}^{-1} \mathrm{yr}^{-1}\right]$} \\
\hline 0 & 0 & 318 & 0 & 8.9 & 8.9 \\
\hline-10 & 4.1 & 143 & 0 & 4.0 & 8.1 \\
\hline-20 & 8.2 & 0 & 7.2 & 1.9 & 10 \\
\hline-30 & 12.2 & 0 & 9.8 & 2.6 & 14.8 \\
\hline-40 & 16.3 & 0 & 16.6 & 4.4 & 20.7 \\
\hline-50 & 20.4 & 0 & 17.0 & 4.5 & 24.9 \\
\hline-60 & 24.5 & 0 & 6.8 & 1.8 & 26.2 \\
\hline-70 & 28.5 & 0 & 0.75 & 0.2 & 28.7 \\
\hline-80 & 32.6 & 0 & 0 & 0 & 32.6 \\
\hline-90 & 36.7 & 0 & 0 & 0 & 36.7 \\
\hline-100 & 40.7 & 0 & 0 & 0 & 40.7 \\
\hline
\end{tabular}

The estimation of the soil subsidence taking place per polder subunit based on historical values is used as an input for calculation of the GHG emissions for method 3.

For method 4, only peat meadow surface area is needed to estimate the $\mathrm{CO}_{2}$ emissions.

\subsection{Calculation of GHG emissions for different policies}

In the study area, four different policies were compared: (1) standard policy (assumption: GHG emissions are not affected as the water authority lowers the surface water levels in the same rate as the soil subsidence), (2) passive rewetting (assumption: soil subsidence is not influenced by this policy, while the (mean and lowest) ground water levels are affected), (3) submerged drains (assumption: soil subsidence is half of measured soil subsidence, meaning that only the $\mathrm{CO}_{2}$-emissions are affected for methods 1,2 and 3 (see Ta- ble 1), based on the PBL study, van den Born et al., 2016), (4) surface water level is lowered at a maximum rate of $6 \mathrm{~mm} \mathrm{yr}^{-1}$ (assumption: GHG emissions are lowered proportionally to the lower GHG emissions, comparing standard policy and passive rewetting and the actual soil subsidence (of $8.3 \mathrm{~mm} \mathrm{yr}^{-1}$ )).

GHG estimations based on method 4 (peat meadow surface) are not influenced by policy scenario as the surface area is not affected.

Also for the polders Groot-Wilnis and Wilnis-Veldzijde GHG emissions are estimated for the policy passive rewetting and compared to standard policy (with the same assumptions as in case of only polder subunit 9). 

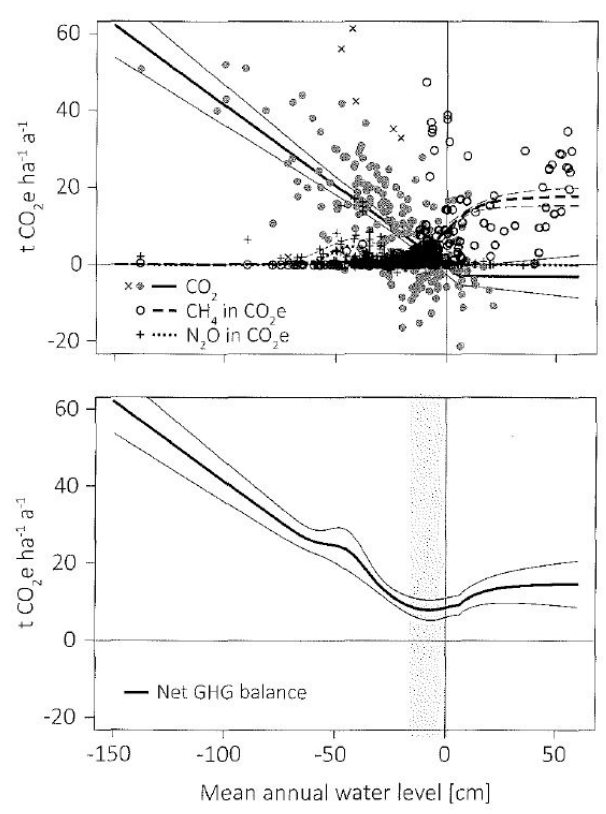

Figure 3. GHG emissions and net GHG balance of peatlands depend on the average annual water table. The hairline graphs illustrate the $95 \%$ confidence intervals, respectively (Jurasinski et al., 2016).

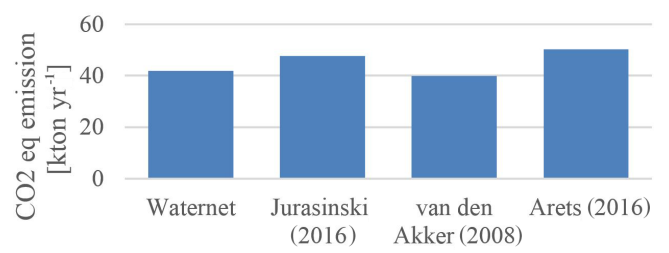

Figure 4. Estimation of total GHG emissions in Groot-Wilnis Vinkeveen and surrounding area (for different methods: Table 1).

\section{Results and Discussion}

\subsection{Calculation of GHG emissions with different methods}

The calculated total GHG emissions in Groot Wilnis Vinkeveen and surrounding area were comparable for all methods, ranging from 42 upto $50{\mathrm{kton} \mathrm{CO}_{2} \text {-eq yr}}^{-1}$, or $14.5-19 \mathrm{tCO}_{2}$-eq ha ${ }^{-1} \mathrm{yr}^{-1}$ see Fig. 4.

Figure 5 shows the calculation of GHG emission in the research area (Groot-Wilnis Vinkeveen and Wilnis-Veldzijde) based on mean ground water level (Jurasinski et al., 2016) with a correction for clay cover.

The methods to estimate GHG emissions differ. In case of applying method of Waternet and Jurasinski, besides $\mathrm{CO}_{2}$ emissions, also $\mathrm{N}_{2} \mathrm{O}$ and $\mathrm{CH}_{4}$ emissions are estimated. The proportion of these emissions are about $20 \%$ of the current emissions (Jurasinski et al., 2016) upto about $28 \%$ (of the current emissions using Waternet method).
However, methane emissions are expected at relatively high ground water levels and therefore are normally only a small portion of the total GHG emissions in agricultural peat meadows for both methods.

There is uncertainty about how accurate the different methods are, especially regarding the $\mathrm{N}_{2} \mathrm{O}$ emissions.

It is stated that the hairline graphs illustrate the $95 \%$ confidence intervals for method 2 , it seems however, that there is a high variability measured on GHG emissions (Jurasinski et al., 2016), see Fig. 3.

$\mathrm{N}_{2} \mathrm{O}$ emissions are expected to be relatively high at mean groundwater levels around $50 \mathrm{~cm}$ (Jurasinski et al., 2016). In case of applying the Waternet method, these emissions are expected to be higher at lower groundwater levels (Stoffels, 2009; Kroes et al., 2000). Besides groundwater levels, nitrogen inputs of manure affect $\mathrm{N}_{2} \mathrm{O}$ emissions.

Note that the global warming potential in the Waternet method was not updated of $\mathrm{N}_{2} \mathrm{O}$ and $\mathrm{CH}_{4}$, which leads to an overestimation of $\mathrm{N}_{2} \mathrm{O}$ emissions in case of the Waternet method: this proportion would be about $22 \%$ instead of $26 \%$ of total current GHG emissions if the global warming potentials would be updated.

Besides the presented methods in this paper, also other methods exist to calculate GHG emissions from agricultural peat lands, for example measurements of $\mathrm{CO}_{2}$ emissions in Dutch peatlands (Fritz et al., 2017). This method is highly similar to the method of Jurasinski et al. (2016), though based on Dutch measurements and also applied in the method of the Green Deal Nationale Koolstofmarkt (GDNK) to valorize $\mathrm{CO}_{2}$ emissions reductions in peat (GDNK, 2018).

Another method which is not shown in this paper is to use the land subsidence model Phoenix in RE:PEAT, which determines land subsidence in peat soils based on mean lowest groundwater level, in combination with the $\mathrm{CO}_{2}$ emissions based on this predicted soil subsidence by van den Akker et al. (2008) as also is used in the PBL study (van den Born et al., 2016).

\subsection{Comparison of influence of different policies on GHG emissions}

In Fig. 6, the GHG emissions are shown for different methods for polder subunit 9 .

The estimations of the effect of different policies on GHG emissions differ, and these estimations are sensitive to the assumptions made. Therefore, the methods presented in this paper are rough concerning GHG emission estimations.

The estimation of GHG emissions based on general numbers (as used in the national counting), shows no effects of measures. This can be expected, as this estimation is only based on peat area and GHG emissions in peat area will only lower if soil types are changed, for small peat layers this means that if the peat disappears due to oxidation of the peat, also the GHG emissions will be lowered. This means that the efforts to lower soil subsidence and GHG emissions related 

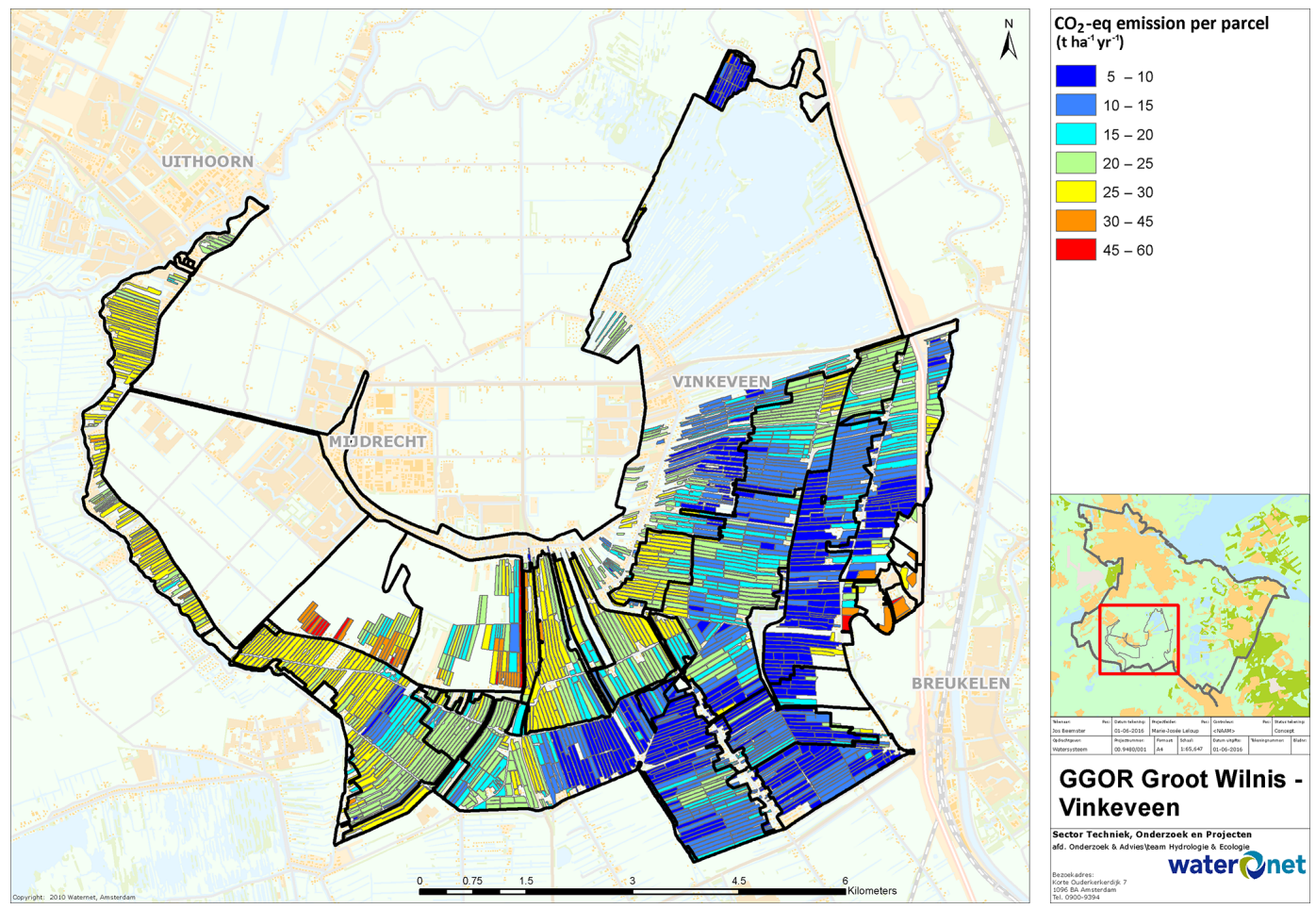

Figure 5. Calculated current $\mathrm{CO}_{2}$-eq emission per parcel in Groot-Wilnis Vinkeveen and Wilnis-Veldzijde based on mean ground water level (Jurasinski et al., 2016) with a correction for clay cover (source of topographic underlayer: (C) Kadaster, 2016).

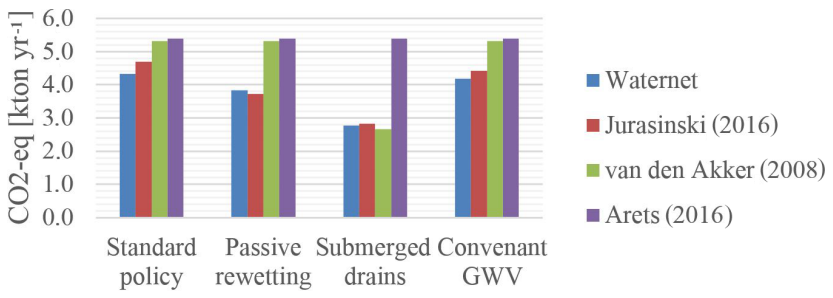

Figure 6. GHG emissions with four different policies in polder subunit 9.

to this soil subsidence will not show effect on the national counting.

Emissions are lowest in case of applying submerged drains, decreasing GHG emissions by $35 \%-50 \%$ depending on the method applied (see Fig. 6). In this estimation, the assumption is made that soil subsidence is lowered by $50 \%$ and the $\mathrm{CO}_{2}$-emissions are reduced likewise based on the study of PBL (van den Born et al., 2016). However, the real effect on soil subsidence and GHG emissions is unknown. In another study, the effect of submerged drains on GHG emission reduction was much lower in AGV peat area (Troost et al., 2018). In this study, GHG emissions estimation were only based on mean groundwater levels (Jurasinski et al., 2016). As submerged drains have little effect on mean groundwater levels (with lower groundwater levels in winter and higher groundwater levels in summer), GHG emissions were more similar to standard policy.

The value of the lower GHG emissions can also be quantified: the lower emissions in this polder subunit in case of submerged drains represent a value of about 550930 EUR ha ${ }^{-1} \mathrm{yr}^{-1}$ (at a price of EUR 100 per ton, conform the policy of AGV, AGV, 2019). For the whole polder sub-

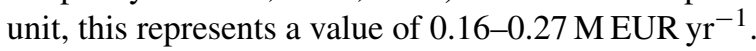

The scenario passive rewetting leads to a decrease of about $12 \%-21 \%$ after 10 years, or $2-3 \mathrm{tCO}_{2}$-eq ha ${ }^{-1} \mathrm{yr}^{-1} \mathrm{com}-$ pared to standard policy, representing a value of about $0.05-$ $0.1 \mathrm{MEUR} \mathrm{yr}^{-1}$ for the polder subunit, using the methods of Waternet and Jurasinski et al. (2016).

In this study, it is assumed that the soil subsidence is not influenced by the policy of passive rewetting or maximum water level change (of $6 \mathrm{~mm} \mathrm{yr}^{-1}$ ). This is a simplification, in fact it is expected that the soil subsidence will be lowered by applying these policies, meaning that the effects of these policies on groundwater levels are overestimated. The real reduction on GHG emissions will therefore probably be lower than presented in this study.

The method of Jurasinski is based on mean groundwater levels (Jurasinski et al., 2016). However, it is expected that highest emissions take place in summer with lower groundwater levels.

For the whole polder Groot-Wilnis Vinkeveen and Wilnis Veldzijde, it is expected that passive rewetting leads to 
9\%-12\% GHG reduction compared to standard policy after 10 years (results not shown), thus a reduction of about 3.7-5.8 kton $\mathrm{CO}_{2}-\mathrm{eq} \mathrm{yr}^{-1}$, or $1-2 \mathrm{tCO}_{2}-\mathrm{eq} \mathrm{ha}^{-1} \mathrm{yr}^{-1} \mathrm{com}-$ pared to standard policy, representing a value of about $0.37-$ $0.58 \mathrm{MEUR}^{-1}$ for the polder Groot-Wilnis and Wilnis Veldzijde, using the methods of Waternet and Jurasinski et al. (2016).

\section{Conclusions}

Different methods were compared to estimate GHG emissions in agricultural peat land areas, which lead to comparable current GHG emission estimations. However, not all methods can be used to analyze effects of different policies on GHG emissions.

In this paper, different methods are used to analyze the effects of different policies on GHG emissions. This procedure will be used by the water authority AGV in the future to support water level management in areas with peat soils. It is recommended to update these methods regularly when new insights become available on GHG emissions in agricultural peat land areas.

In this paper, it was shown that different water management policies will affect GHG emissions in the study area. Within the scenario's compared, GHG emissions are expected to be decreased most by applying submerged drains. Estimations of GHG emission reductions depend on assumptions made.

Data availability. The underlying research data is stored in a database of Waternet (not public).

Author contributions. AMMW took the lead in writing this paper. JB performed the groundwater modelling and contributed in writing the paper.

Competing interests. The authors declare that they have no conflict of interest.

Special issue statement. This article is part of the special issue "TISOLS: the Tenth International Symposium On Land Subsidence - living with subsidence". It is a result of the Tenth International Symposium on Land Subsidence, Delft, the Netherlands, 17-21 May 2021.

Acknowledgements. The idea of this work was given by Bart Specken. Corine van den Berg was the commissioner of the work. Johan Ellen provided the measured soil subsidence in Groot-Wilnis Vinkeveen and surrounding area. Marie-Josée Leloup provided the policy scenarios that were compared. Tim Pelsma helped on critical reviewing the work. Christian Fritz from Radboud University
Nijmegen provided literature background on estimating GHG emissions.

\section{References}

AGV: Waterbetrokken. Bestuursakkoord Waterschap Amstel, Gooi en Vecht 2019-2023, available at: https://www.agv.nl/siteassets/documenten/waterbetrokkenbestuursakkoord-waterschap-amstel-gooi-en-vecht-201920232.pdf (last access: 28 February 2020), 2019.

Arets, E. J. M. M., van der Kolk, J. W. H., Hengeveld, G. M., Lesschen, J. P.,Kramer, H., Kuikman, P. J., and Schelhaas, M. J.: Greenhouse Gas reporting for the LULUCF sector in the Netherlands. Methodolgical background. Wot Technical report. Statutory Research Task Unit for Nature \& the Environment (WOT Natuur \& Milieu), Wageningen UR, Wageningen, The Netherlands, available at: https://english.rvo.nl/sites/default/ files/2017/07/LULUCF_methodology_report_2016.pdf (last access: 28 February 2020), 2016.

Fritz, C., Geurts, J., Weideveld, S., Temmink, R., Bosma, N., Wichem, F., Smolders, F., and Lamers, L.: Effect van peilbeheer en teeltkeuze op $\mathrm{CO}_{2}$-emissies en veenoxidatie. Meten is weten bij bodemdaling-mitigatie, Bodem, 2 20-22, 2017.

GDNK: Methode voor vaststelling van emissiereductie $\mathrm{CO}_{2}$-eq, Type project: $\mathrm{CO}_{2}$-emissiereductie via verhoging grondwaterpeil in veengebieden ('Valuta voor Veen'), available at: http://nationaleco2markt.nl/wp-content/uploads/2018/10/ GDNK-Groen-Veenweide-001.pdf (last access: 28 February 2020), 2018.

IPCC: Fourth Assessment Report, Chapter 2: Changes in Atmospheric Constituents and in Radiative Forcing, Cambridge University Press, Cambridge, UK, 234 pp., 2007.

IPCC: Fifth Assessment Report, available at: https: //archive.ipcc.ch/pdf/assessment-report/ar5/syr/SYR_AR5_ FINAL_full_wcover.pdf (last access: 28 February 2020), 2014.

Jurasinski, G., Günther, A., Huth, V., Couwenberg, J., and Glatzel, S.: 5.1 Greenhouse gas emissions, 79-93, Deel van hoofdstuk 5 Ecosystem services provided by paludiculture; Book: W. Wichtmann, C. Schröder \& H. Joosten, 2016, Paludiculture - productive use of wet peatlands, Climate protection - biodiversity regional economic benefits. Schweizerbart Science Publishers. Stuttgart), 2016.

Kroes, J. G., van der Bolt, F. J. E., Groenendijk, P., Hoving, I. E., and de Haan, M. H. A.: Beperking van lachgas door waterbeheer; een systeemanalyse, Alterra rapport 114-6, Alterra, Wageningen, 83 pp., 2000.

RIVM: Greenhouse Gas Emissions in the Netherlands 1990-2014 National Inventory Report 2016, available at: https://www.rivm. nl/bibliotheek/rapporten/2016-0047.pdf (last access: 28 February 2020), 2016.

Stoffels, J.: Natuurlijke broeikasgasemissies vanuit de veenweidegebieden van AGV; een literatuurstudie, Internal report Waternet, 2009.

Troost, S., Kuipers, H., and Hoefsloot, N.: Toekomstverkenning bodemdaling AGV, Report HJGK/001/162262, 2018.

Van den Akker, J. J. H., Kuikman, P. J., de Vries, F., Hoving, I., Pleijter, M., Hendriks, R. F. A., Wolleswinkel, R. J., Simões R. T. L., and Kwakernaak, C.: Emission of $\mathrm{CO}_{2}$ from Agricultural 
peat soils in the Netherlands and ways to limit this emission, in: Proceedings of the 13th International Peat Congress After Wise Use - The Future of Peatlands, edited by: Farrell, C. and Feehan, J., Vol. 1 Oral Presentations, Tullamore, Ireland, 8-13 June 2008, 645-648, 2008
Van den Born, G. J., Kragt, F., Henkens, D., Rijken, B., van Bemmel, B., and van der Sluis, S.: Dalende bodems, stijgende kosten. Mogelijke maatregelen tegen veenbodemdaling in het landelijk en stedelijk gebied, PBL 1064, available at: $\quad$ https://www.pbl.nl/sites/default/files/cms/publicaties/ pbl-2016-dalende-bodems-stijgende-kosten-1064.pdf (last access: 28 February 2020), 2016. 